\title{
METABOLIZABLE ENERGY OF RICE BRAN, COTTONSEED MEAL AND WHEAT BRAN FOR SLOW-GROWING BROILERS AT TWO AGES
}

\author{
ENERGIA METABOLIZÁVEL DOS FARELOS DE ARROZ, ALGODÃO E \\ TRIGO PARA FRANGOS DE CRESCIMENTO LENTO EM DUAS IDADES
}

\author{
Felipe Dilelis ${ }^{*}$ ORCID - http://orcid.org/0000-0002-9681-4775 \\ Augusto Vidal da Costa Gomes ${ }^{1}$ ORCID - http://orcid.org/0000-0003-0980-4550 \\ Cristina Amorim Ribeiro de Lima' ORCID - http://orcid.org/0000-0003-2018-5965 \\ Débora Costa Barroso Corrêa2 ORCID - http://orcid.org/0000-0002-8818-4451 \\ Tulio Leite Reis ${ }^{3}$ ORCID - http://orcid.org/0000-0003-2141-8740
}

\author{
${ }^{1}$ Universidade Federal Rural do Rio de Janeiro, Seropédica, RJ, Brazil. \\ ${ }^{2}$ Instituto Federal de Rondônia - Campus Cacoal, Cacoal, RO, Brazil. \\ ${ }^{3}$ Universidade Federal Rural do Rio de Janeiro, Campos dos Goytacazes, RJ, Brazil \\ *Correspondent author - fdilelis@ufrri.br
}

\begin{abstract}
The aim of this study was to evaluate bromatological composition and metabolizable energy values of cottonseed meal, rice meal, and wheat bran when provided to slow growth rate broilers at different ages. Energy values of 15- to 25- and 35- to 45-day-old broilers were determined by the total feces collection method using two digestibility bioassays. The birds were distributed in a completely randomized experimental design to evaluate the age effect, with six replicates of 10 chickens each, for each ingredient. Values of apparent metabolizable energy adjusted by nitrogen balance ( $\mathrm{kcal} / \mathrm{kg}$ ), for the first and second ages were: 1,255 and 1,564 for cottonseed meal, 3,124 and 3,301 for rice meal, and, 2,211 and 2,383 for wheat bran, respectively. The ingredients showed some variations regarding chemical composition and energy values, which were higher $(\mathrm{P}<0.05)$ in older broiler chickens.
\end{abstract}

Keywords: energetic value, feed chemical composition; free-range broiler, total excreta collection

\section{Resumo}

O objetivo nesta pesquisa foi determinar a composição bromatológica e os valores de energia metabolizável para frangos de corte de crescimento lento em diferentes idades dos ingredientes: farelo de algodão, farelo de arroz e farelo de trigo. Para determinação dos valores energéticos foi utilizado o método de coleta total de excretas em dois ensaios de digestibilidade de 15 a 25 e de 35 a 45 dias de idade. As aves foram distribuídas em delineamento inteiramente casualizado, avaliando o efeito da idade, com seis repetições constituídas de 10 aves, para cada ingrediente. Os valores de energia metabolizável aparente corrigida pelo balanço de nitrogênio $(\mathrm{kcal} / \mathrm{kg})$, para primeira e segunda idade respectivamente, foram: farelo de algodão, 1.255 e 1.564; farelo de arroz, 3.124 e 3.301; farelo de trigo, 2.211 e 2.383. Os alimentos apresentaram variação quanto a composição química, bem como o valor energético foi superior $(\mathrm{P}<0,05)$ para os frangos de maior idade.

Palavras-chave: coleta total de excretas; composição química de alimentos; frango caipira; valor energético. 
Received on: April 11th, 2017.

Accepted on: April, 3rd, 2019

\section{Introduction}

Food energy content is one of the important components of poultry diets as energy is required from maintenance to maximizing poultry productive potential. The energy content present in feed can be expressed by several methods in which metabolizable energy is the most usual tool used in poultry nutrition $^{(1)}$.

Aiming to decrease feed costs, alternative ingredients to maize and soybean meal in poultry rations have been studied by several researchers. For slow-growing broiler lineages, the studies can have special interest once these birds have their own physiological characteristics with possible nutritional impacts, e.g., better fiber-diet digestibility after 31 days of age compared to fast-growing lineages ${ }^{(2)}$. In contrast, although peculiarities exist regarding the development of the digestive system organs and the serum biochemical parameters, no differences were found in the activity of the pancreatic enzymes lipase and amylase, indicating similar capacity of nutrients digestion among lineages ${ }^{(3)}$.

Rice meal and wheat bran are energetic feedstuffs that are possible to be used instead of corn, as the price of corn increases, especially during off-season periods. Furthermore, rice and wheat have higher protein content than corn with the lowest inclusion being possibly of soybean meal in the diets. Soybean meal is the most important source of protein in poultry nutrition worldwide, but the increasing demand has increased the price, sometimes requiring the use of other protein sources. Cottonseed meal is a by-product of the cotton oil industry, a rich source of protein, but higher in fiber and antinutritional factors, being used as a partial replacement of soybean meal in poultry diets.

Several factors influence the metabolizable energy values of feedstuffs, for example, age; young birds have a lower digestibility and higher sensibility to antinutritional factors than older birds which have a digestive tract that is more developed and has a higher absorption capacity ${ }^{(4)}$. In addition, the endogenous losses also decrease with the advancing age in birds and can directly affect the apparent metabolizable energy values ${ }^{(5)}$. The best energetic utilization of ingredients and complete rations by older chickens has been described in both fast-growing broilers ${ }^{(6-8)}$ and slow-growing broilers ${ }^{(9-11)}$.

Determining bromatological composition and feed energy values are lengthy and costly processes, requiring the use of nutritional tables to obtain the energetic nutritional values of the feed. Nonetheless, to update this data, information is required to complement and improve these tables. Owing to the small number of studies available, the diets for slow-growing broilers are usually calculated using energy values of ingredients obtained from fast-growing broilers, which can result in poor feed conversion as well as higher accumulation of abdominal fat ${ }^{(12)}$. Thus, the objective of this study was to determine the chemical composition and the metabolizable energy values of rice bran, cottonseed meal, and wheat bran in slow-growing broilers at two ages.

\section{Material and methods}

To determine the energy values of ingredients in slow-growing broilers, two metabolism assays were performed in the poultry metabolism laboratory. All procedures of this project were approved by the 
ethics committee for animal research (CEUA) of the Universidade Federal Rural do Rio de Janeiro under protocol number 23083.001321/2012-04.

The ingredients evaluated were cottonseed meal, rice meal, and wheat bran. For chemical composition the following analyses were performed according to the Association of Official Analytical Chemistry ${ }^{(13)}$ : dry matter (DM), crude protein (CP), ether extract (EE), crude fiber (CF), and ash. Neutral detergent fiber (NDF) and acid detergent fiber (ADF) were determined according to Van Soest et al. ${ }^{(14)}$; gross energy (GE) was determined using the IKA C 2000 calorimeter (IKA Brasil, Campinas, SP, Brazil); and $\mathrm{Ca}$ and $\mathrm{P}$ were determined according to the Adolfo Lutz Institute methodology ${ }^{(15)}$.

Determination of apparent metabolizable energy values (AME), nitrogen-corrected apparent metabolizable energy (AMEn), dry matter metabolization coefficient (DMMC), apparent energy metabolization coefficient (EMC), and nitrogen-corrected apparent energy metabolization coefficient (EMCn) were estimated throughout the two total feces collection bioassays.

Two hundred and forty 1-day-old males of the broiler strain Redbro Plumé (Vermelho Pesado - C44), selected for slow growth rate, were housed in 24 metabolic cages, measuring $0.90 \mathrm{~m} \times 0.60 \mathrm{~m} \times 0.45 \mathrm{~m}$. All birds from 1 to 14 days old received an initial ration formulated to attend all of their nutritional exigencies according to Rostagno et al. ${ }^{(16)}$. The treatments comprised three ingredients evaluated during two periods: 15 to 25 days and 35 to 45 days in a completely randomized experimental design with six replicates of 10 birds each, for each ingredient evaluated.

To perform energy value calculations, a group of broilers received a reference diet (Table 1) while the other three groups received different treatments comprising $60 \%$ of the reference diet and $40 \%$ of the ingredient to be evaluated, except for cottonseed meal, which replaced $20 \%$ of the reference diet owing to its high crude fiber content.

On day 15, all chicks were weighed (average weight of $353.03 \pm 11.06 \mathrm{~g}$ ) and housed in metabolic cages. The birds were maintained under experimental conditions for $5 \mathrm{~d}$ of adaptation. This was followed by twice daily collection of total excreta samples for $5 \mathrm{~d}$. Feces were weighed, packed in identified plastic bags, and stored in a freezer $\left(-10^{\circ} \mathrm{C}\right)$ immediately after each collection until further analyses.

The total excreta produced and feed consumed per experimental unit were computed at the end of the trial. During the interval between experimental periods, the birds received a balanced growing ration, attending all nutritional exigencies.

On day 35, the second metabolic assay was initiated. The birds chicks were weighed (average weight of $1,291 \pm 80.37 \mathrm{~g}$ ) and housed in metabolic cages. The procedures of management and collection were similar to those described in the prior metabolic assay.

Feces were thawed, weighed, and homogenized at the end of the experiment; $250 \mathrm{~g}$ of each sample was subjected to further analyses. Material was pre-dried in forced ventilation at $55{ }^{\circ} \mathrm{C}$ for $72 \mathrm{~h}$ followed by grinding to $1 \mathrm{~mm}$. The excreta and experimental rations were submitted to analyses of $\mathrm{DM}, \mathrm{N}$, and GE. 
Table 1. Composition and nutrient content of feed ingredients of the reference diet

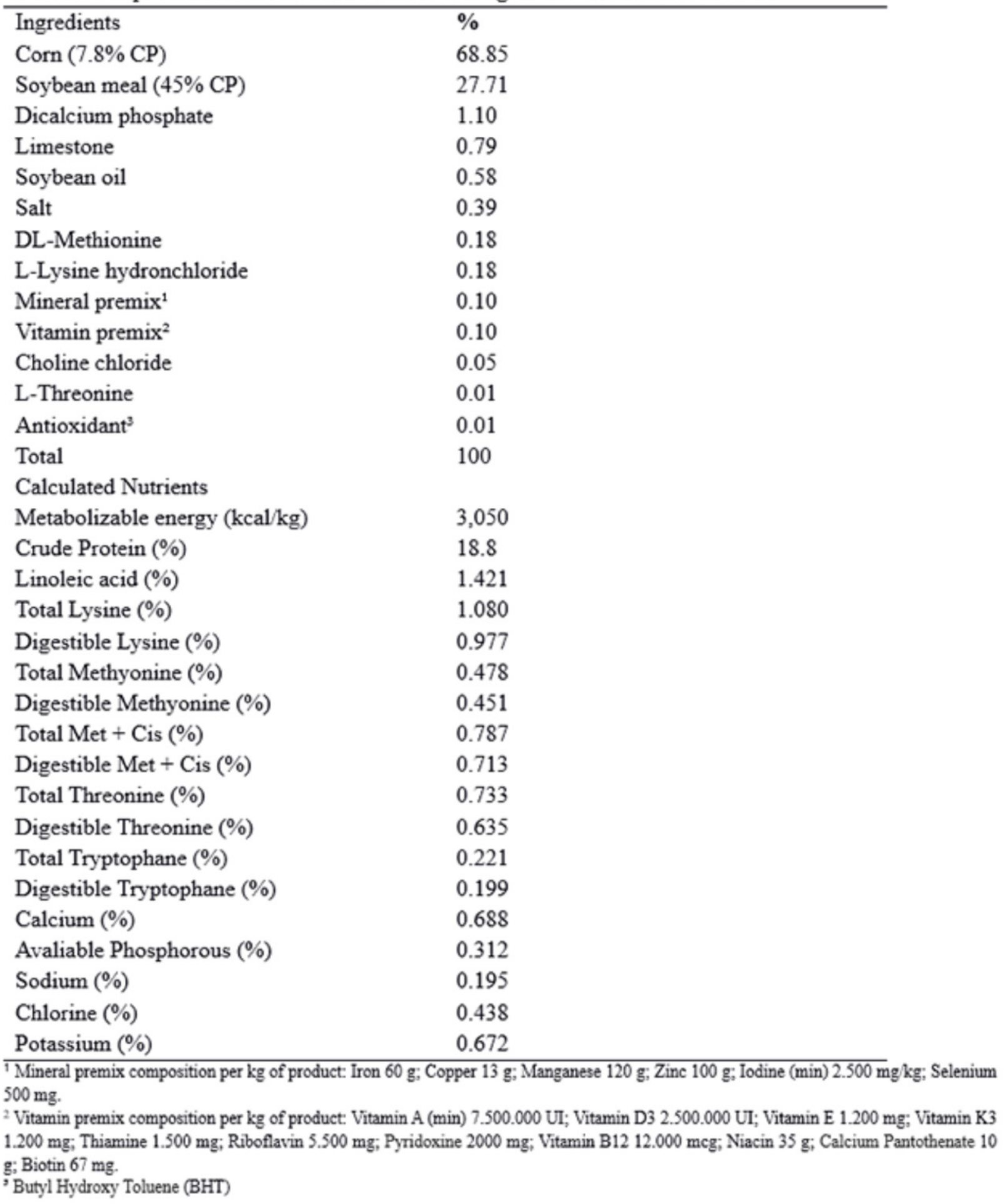

Equations described by Matterson et al. ${ }^{(17)}$ were applied to determine the values of AME and AMEn. For DMMC, EMC, and EMCn, the followings equations were used:

$$
\mathrm{EMC}=\frac{\mathrm{AME}}{\mathrm{GE}} \times 100
$$




$$
\begin{gathered}
\mathrm{EMCn}=\frac{\mathrm{AMEn}}{\mathrm{GE}} \times 100 \\
\text { DMMC }=\frac{\text { DMintake }- \text { DMoutput }}{\text { DMintake }} \times 100
\end{gathered}
$$

Data were submitted to variance analyses and ages were compared using the F-test at the $5 \%$ significance level for each ingredient evaluated using SISVAR ${ }^{(18)}$.

\section{Results and discussion}

Chemical composition and gross energy values are listed in Table 2. Variations in the results were observed in comparison to values reported in national ${ }^{(16,19,20)}$ and international literature ${ }^{(21,22)}$. These differences may occur owing to variations in weather, type of soil, storage, and mainly sub products as a consequence of variable processes of extraction.

Table 2. Chemical composition and gross energy values of the tested ingredients ${ }^{2}$

\begin{tabular}{llll}
\hline Item & Cottonseed Meal & Rice Meal & Wheat Bran \\
\hline Dry matter (\%) & 88.45 & 88.31 & 87.42 \\
Crude Protein (\%) & 30.68 & 12.59 & 15.49 \\
Ether extract (\%) & 3.53 & 19.72 & 4.37 \\
Ash (\%) & 4.67 & 10.71 & 4.45 \\
Crude fiber (\%) & 21.74 & 9.68 & 7.34 \\
Neutral detergent fiber (\%) & 46.76 & 26.56 & 36.29 \\
Acid detergent fiber (\%) & 29.95 & 15.72 & 10.09 \\
Phosphorous (\%) & 0.65 & 1.82 & 0.83 \\
Calcium (\%) & 0.19 & 0.07 & 0.062 \\
Crude energy (kcal $/ \mathrm{kg})$ & 4,082 & 4,477 & 3,997 \\
\hline
\end{tabular}

Values expressed in natural matter

Cottonseed meal showed $30.68 \%$ CP whereas values between $25 \%{ }^{(23)}$ to $41 \%^{(21)}$ were also found in the literature. The chemical composition of cotton meal was close to that described by Rostagno et al. ${ }^{(16)}$, except for the EE; in the present study, this chemical composition was found to be of a superior value $(3.53 \%)$ than that cited by the author $(1.26 \%)$. In contrast, Rezende et al. ${ }^{(23)}$ found values higher than that previously mentioned for cottonseed meal $(9 \%$ EE). These differences in EE content could be attributed to the extraction method using mechanical or solvent removal, in which solvent removal results in cotton brans with low EE content ${ }^{(24)}$.

Rice meal showed similar values for $\mathrm{CP}$ and ash, and higher values for $\mathrm{EE}, \mathrm{NDF}, \mathrm{ADF}$, and $\mathrm{CF}$ than 
those reported in the Brazilian Tables for Poultry and Swine ${ }^{(16)}$. The rice meal analyzed presented a higher GE value than that reported in the literature ${ }^{(16,21,25)}$ owing to its elevated EE content.

NDF, ADF, and CF values of wheat bran were lower than those cited by Rostagno et al. ${ }^{(16)}$; however, values of $\mathrm{CP}$ were similar, and those of $\mathrm{EE}$ and $\mathrm{GE}$ were higher. In the literature, $\mathrm{CP}$ content of wheat bran is described as between $13.01 \%$ to $19.06 \%^{(26,27)}$. In the present study, CP and CF values were lower than those reported by Babiker et al. ${ }^{(22)}$ (18.69\% and 8.75\%, CP and CF, respectively). Assessing four different wheat brans, Nunes et al. ${ }^{(28)}$ reported gross energy values of 3,071 and 4,020 $\mathrm{kcal} / \mathrm{kg}$. In this study, 3,997 kcal/kg GE was determined for wheat bran.

Ingredients evaluated showed superior AME and AMEn values $(\mathrm{P}<0.05)$ at $35-45$ days of age, indicating the ingredients were better used by the older broilers. According to Batal and Parsons ${ }^{(29)}$, AME and AMEn values are affected by the age of the birds, owing to a better nutrient digestibility, mainly of starch and fat with the growth of the birds.

The values of AME and AMEn determined for the different ages are presented in Table 3.

Table 3. Ingredients apparent metabolizable energy (AME) and nitrogen-corrected apparent metabolizable energy (AMEn) at different ages ${ }^{1}$

\begin{tabular}{|c|c|c|c|c|}
\hline \multirow{2}{*}{ Feed } & \multicolumn{2}{|c|}{$\mathrm{AME}(\mathrm{kcal} / \mathrm{kg})$} & \multicolumn{2}{|c|}{$\operatorname{AMEn}(\mathrm{kcal} / \mathrm{kg})$} \\
\hline & $15-25$ & $35-45$ & $15-25$ & $35-45$ \\
\hline Cottonseed Meal & $1,394^{b}$ & $1,792^{2}$ & $1,255^{b}$ & $1,564^{2}$ \\
\hline $\mathrm{CV}^{2}(\%)$ & 6.81 & & 6.05 & \\
\hline Rice Meal & $3,243^{b}$ & $3,439^{2}$ & $3,124^{b}$ & $3,301^{2}$ \\
\hline $\mathrm{CV}^{2}(\%)$ & 2.05 & & 2.00 & \\
\hline Wheat Bran & $2,303^{b}$ & $2,479^{2}$ & $2,211^{b}$ & $2,383^{2}$ \\
\hline $\mathrm{CV}^{2}(\%)$ & 5.03 & & 5.25 & \\
\hline
\end{tabular}

Ingredients evaluated showed superior AME and AMEn values $(\mathrm{P}<0.05)$ at $35-45$ days of age, indicating the ingredients were better used by the older broilers. According to Batal and Parsons ${ }^{(29)}$, AME and AMEn values are affected by the age of the birds, owing to a better nutrient digestibility, mainly of starch and fat with the growth of the birds.

Evaluating the effect of age on enzymatic activity and nutrient digestibility of soybean bran and extruded soybean, Sakomura et al. ${ }^{(30)}$ found higher AME and AMEn values in older birds as well as superior pancreas allometric growth and an increase in pancreatic enzymes activity, indicating that as the bird grows, the digestive tract develops and the feed energy utilization is better.

The cottonseed meal evaluated showed 1,394 kcal/kg and 1,792 kcal/kg AME, and 1,255 kcal/Kg and 1,564 kcal/kg AMEn for the first and second age groups, respectively. AMEn values were lower than the standard $(1,666 \mathrm{kcal} / \mathrm{kg})$ found by Rostagno et al. ${ }^{(16)}$, which was obtained with conventional lineage broilers. The results obtained were also lower than those reported by Santos et al. ${ }^{(24)}$ in three different types of cottonseed meal, with AMEn between 2,793 kcal/kg to 2,977 kcal $/ \mathrm{kg}$. This variation may be explained by the crude fiber percentage content of the ingredients studied which was $21 \%$ in the present research, while Rostagno et al. ${ }^{(16)}$ reported $24.93 \%$ and Santos et al. ${ }^{(24)} 7.93 \%$ to $15.94 \%$. 
In addition, Carvalho et al. ${ }^{(20)}$ evaluating cottonseed meal with high crude fiber content (29\%) reported $1,188 \mathrm{kcal} / \mathrm{kg}$ AMEn.

Regarding the two periods of trials, cottonseed meal presented higher values $(28.55 \%$ AME and $24.62 \%$ AMEn) at 35 to 45 days of age than that at 15 to 25 days; consistent with those found by Brumano et al. ${ }^{(6)}$ and Generoso et al. ${ }^{(7)}$, who evaluated AME and AMEn of cottonseed meal provided to conventional linage of broilers at different ages (21-30 and 41-50 days).

The energetic values for rice meal during first and second age were 3,243 kcal/kg and 3,439 kcal/ $\mathrm{kg}$ AME and 3,124 kcal/Kg and 3,301 kcal/Kg AMEn, respectively. Values of AMEn were higher than that reported in different studies: $2.897 \mathrm{kcal} / \mathrm{kg}$, Junqueira et al. ${ }^{(25)} ; 2,521 \mathrm{kcal} / \mathrm{kg}$, Rostagno et al. ${ }^{(16)}$; and 3,075 kcal $/ \mathrm{kg}$, Pontalti et al. ${ }^{(31)}$. These differences are because of the effects of the elevated percentage of EE in rice meal in the present study $(19.72 \%)$.

The AME and AMEn values for rice meal at the second age were greater than those at the first age, $6.05 \%$ and $5.67 \%$, respectively. These values are consistent with the 2,446 kcal $/ \mathrm{kg}$ and 2,650 kcal/ $\mathrm{kg}$ reported by Generoso et al. ${ }^{(7)}$, where values at the second age were $8 \%$ higher than that at the first age, in a study with conventional broilers at 21-30 and 41-50 days of age. However, Mello et al. ${ }^{(8)}$ observed rice meal with different AMEn values when provided to broilers of 10 to 17, 26 to 33, and 40 to 47 days, noticing superior AMEn only when determined in adult roosters.

Wheat bran energetic values at the first and second age were 2,303 kcal/kg and 2,479 $\mathrm{kcal} / \mathrm{kg}$ AME and $2,211 \mathrm{kcal} / \mathrm{kg}$ and $2,333 \mathrm{kcal} / \mathrm{kg}$ AMEn, respectively. The values are similar to those reported by Silva et al. ${ }^{(27)}$ using commercial laying hens, 2,396 kcal $/ \mathrm{kg}$ AME and 2,185 kcal $/ \mathrm{kg}$ AMEn. However, the results were higher than those cited by Nunes et al. ${ }^{(28)}$, which ranged between $1,807 \mathrm{kcal} / \mathrm{kg}$ to $1,972 \mathrm{kcal} / \mathrm{Kg}$ when evaluating four types of wheat bran. Moreover, Rostagno et al. ${ }^{(16)}$ reported 1,795 $\mathrm{kcal} / \mathrm{kg}$ AMEn in wheat bran.

At the second age, AME and AMEn values for wheat bran were superior $(7.64 \%$ and $7.77 \%$, respectively) to the results obtained with broilers at the first age. These results are consistent with those of Generoso et al. ${ }^{(7)}$, who found 1,683 kcal/kg AMEn in broilers aged 21 to 30 days and 1,877 $\mathrm{kcal} / \mathrm{kg}$ in birds aged 41 to 50 days. Mello et al. ${ }^{(8)}$ evaluating birds with different ages reported higher wheat bran AMEn in adult roosters, intermediate content between ages of 26 to 33 and 33 to 40 days, and a lower value at 10 to 17 days of age.

All ingredients showed higher energetic value $(\mathrm{P}<0.05)$ in older birds. Santos et al. ${ }^{(9)}$ found similar results in broilers of slow growth rate (Isa Label), with higher AMEn values in broilers 28 to 35 days old than in 10 to 17 days old broilers, evaluating whole corn germ, sorghum, and soybean meal.

Cottonseed meal (29.95\% ADF) presented a higher difference in AMEn (24.62\%) among the experimental periods. These data are consistent with those of Krás et al. ${ }^{(2)}$, who demonstrated that as birds grow, they improve the digestibility of fiber.

EMC and EMCn values (Table 4) were greater $(\mathrm{P}<0.05)$ in 35 to 45 -day-old birds as also found by Gasparini et al. ${ }^{(10)}$, who reported a linear increase in AME, AMEn, EMC, and EMCn content with growth in nutritional analyses of babassu meal fed to low growing broilers at different ages.

Cottonseed meal DMMC was similar to that reported by Carvalho et al. ${ }^{(20)}$; however, a higher EMC was observed in the current study. EMC values according to Santos et al. ${ }^{(9)}$ with three different processing methods ranged from $55.5 \%$ to $65.2 \%$. 
Rice meal and wheat bran showed higher value of DMMC at the second age evaluated $(\mathrm{P}<0.05)$. In contrast, Pontalti et al. ${ }^{(31)}$ mentioned lower values than in the previous study. Nonetheless, EMC in both studies were similar.

EMC and EMCn content of wheat bran were greater than those cited by Nunes et al. ${ }^{(26)}$, estimating $47.79 \%$ and $46.10 \%$, respectively, and Silva et al. ${ }^{(27)}$ reporting $49.10 \%$ for EMC and $41.18 \%$ for DMMC.

Table 4. Dry matter metabolization coefficient (DMMC) of apparent energy metabolization coefficient $(\mathrm{EMC})$ and nitrogen-corrected apparent energy metabolization coefficient (EMCn) at different ages ${ }^{1}$

\begin{tabular}{|c|c|c|c|c|c|c|}
\hline \multirow{2}{*}{ Ingredient } & \multicolumn{2}{|c|}{ DMMC (\%) } & \multicolumn{2}{|c|}{ EMC (\%) } & \multicolumn{2}{|c|}{ EMCn (\%) } \\
\hline & $15-25$ & $35-45$ & $15-25$ & $35-45$ & $15-25$ & $35-45$ \\
\hline Cottonseed Meal & $26.1^{2}$ & $28.9^{\mathrm{a}}$ & $34.1^{\mathrm{b}}$ & $43.9^{2}$ & $30.7^{\mathrm{b}}$ & $38.3^{2}$ \\
\hline $\mathrm{CV}^{2}(\%)$ & 10.27 & & 6.81 & & 6.05 & \\
\hline Rice Meal & $53.4^{b}$ & $57.0^{2}$ & $72.4^{b}$ & $76.8^{2}$ & $69.7^{\mathrm{b}}$ & $73.7^{2}$ \\
\hline $\mathrm{CV}^{2}(\%)$ & 2.93 & & 2.05 & & 2.00 & \\
\hline Wheat Bran & $46.1^{b}$ & $50.7^{2}$ & $57.9^{b}$ & $62.0^{2}$ & $55.6^{\mathrm{b}}$ & $59.6^{2}$ \\
\hline $\mathrm{CV}^{2}(\%)$ & 7.32 & & 5.03 & & 5.25 & \\
\hline
\end{tabular}

Values expressed in natural matter.

${ }^{2}$ Coefficient of variation

a, b: Means in the same row having different superscript letters are significantly different $(P<0.05)$.

Such differences might be associated with the effect of feed chemical composition, age, and poultry genetic potential on the metabolism bioassays used to obtain the energetic values.

\section{Conclusions}

Chemical composition variations were observed compared to the values cited in the literature. Feed metabolizable energy values were influenced by the age of the birds.

\section{References}

1. Scottá BA, Pereira CMC, Bernardino VMP. Energia Metabolizável e Aminoácidos Digestíveis dos Alimentos para Frangos de Corte. Revista Eletrônica Nutritime. 2012;9(4):1861-1874. Avaiable from: http:// www.nutritime.com.br/arquivos_internos/artigos/170_julho\%202012_pdf Portuguese

2. Krás RV, Kessle AM, Ribeiro AML, Henn JD, Santos II, Halfen DP, Bockor L. Effect of dietary fiber, genetic strain and age on the digestive metabolism of broiler chickens. Brazilian Journal of Poultry Science [Internet]. 2013;15(2):83-90. Available from: http://www.scielo.br/pdf/rbca/v15n2/03.pdf Portuguese

3. Santos FR, Stringhini JH, Freitas NF, Minafra CS, Oliveira PR, Duarte EF, Guimarães GS. Morphological and morphometric aspects of the digestive apparatus, serum biochemical measures and activity of pancreatic enzymes of slow- and fast-growing broilers. Revista Brasileira de Ciências Agrárias [Internet]. 2015;10(2):32227. Available from: https://doi.org/10.5039/agraria.v10i2a4370 Portuguese

4. Freitas ER, Sakomura NK, Ezequiel JMB, Neme R, Mendonça MO. Metabolizable energy of feeds on diet formulation for broilers. Pesquisa Agropecuária Brasileira [Internet]. 2006;41(1):107-115. Available from: 
http://www.scielo.br/pdf/pab/v41n1/28147.pdf Portuguese

5. Silva EP, Rabello CB, Lima MB, Lima SBP, Lima RB, Lima TS. Age effect on the endogenous and metabolic losses in broiler chickens and free range. Ciência Animal Brasileira [Internet]. 2011;12(1):37-47. Available from: https://www.revistas.ufg.br/vet/article/view/5096/8896 Portuguese

6. Brumano G, Gomes PC, Albino LFT, Rostagno HS, Generoso RAR, Schmidt M. Chemical composition and metabolizable energy values of protein feedstuffs to broilers at different ages. Revista Brasileira de Zootecnia [Internet]. 2006;35(6):2297-2302. Available from: http://www.scielo.br/pdf/rbz/v35n6/14.pdf Portuguese

7. Generoso RAR, Gomes PC, Rostagno HS, Albino LFT, Barreto SLT, Brumano G. Chemical and energy composition of some feeds for broiler chicks and two ages. Revista Brasileira de Zootecnia [Internet]. 2008;37(7):1251-1256 Available from: http://www.scielo.br/pdf/rbz/v37n7/16.pdf Portuguese

8. Mello HHC, Gomes PC, Rostagno HS. Metabolizable energy values of feedstuffs obtained from poultry at different ages. Revista Brasileira de Zootecnia [Internet]. 2009;38(5):863-868. Available from: http://www. scielo.br/pdf/rbz/v38n5/12.pdf Portuguese

9. Santos FR, Stringhini JH, Oliveira PR, Duarte EF, Minafra CS, Café MB. Values of Metabolizable Energy and Metabolization of Nutrients for Slow- and Fast-growing Birds at Different Ages. Brazilian Journal of Poultry Science [Internet]. 2015;17(4):517-522, 2015. Available from: http://www.scielo.br/pdf/rbca/v17n4/1516635X-rbca-17-04-00517.pdf English

10. Gasparini SA, Ribeiro FB, Siqueira JC, Bonfim MAD, Nascimento DCN. Nutritional evaluation of babassu cake for slow growth broilers atdifferent ages. Revista Caatinga [Internet]. 2015;28(2):126-34. Available from: https://periodicos.ufersa.edu.br/revistas/index.php/caatinga/article/view/3702/5666 Portuguese

11. Fernandes RTV, Arruda AMV, Araújo AS, Melo AS, Marinho JBM, Vasconcelos NVB, Lopes FF, Holanda JS. Energy values and digestibility coefficients of a traditional ration for Label Rouge poultry in different ages. Acta Veterinaria Brasilica [Internet]. 2015;9(2):108-13, 2015. Available from: http://dx.doi.org/10.21708/ avb.2015.9.2.4255 Portuguese

12. Santos FR, Stringhini JH, Minafra CS, Almeida RR, Oliveira PR, Duarte EF, Silva RB, Cafe MB. Feed formulation for slow-growing broilers using metabolizable energy values of food determined with strains of slow and fast growing. Arquivos Brasileiros de Medicina Veterinária e Zootecnia [Internet]. 2014;66(6):183946. Available from: http://www.scielo.br/pdf/abmvz/v66n6/0102-0935-abmvz-66-06-01839.pdf Portuguese

13. Association of Official Analytical Chemistry -AOAC. Official methods of analysis. 16.ed. Arlington, AOAC International, 1995. 1025p.

14. Van Soest PJ, Robertson JD, Lewis BA. Methods for dietary fiber, neutral detergent fiber and non-starch polysaccharide in relation to animal nutrition. Journal Dairy Science. 74(10):3583-97.

15. Instituto Adolfo Lutz. Métodos físico-químicos para análise de alimentos. São Paulo: Instituto Adolfo Lutz, 2008. $1^{\text {a }}$ Edição Digital. Available from: http://www.ial.sp.gov.br/resources/editorinplace/ial/2016_ 3 19/ analisedealimentosial_2008.pdf Portuguese

16. Rostagno HS, Albino LFT, Donzele JL, Gomes PC, Oliveira RFM, Lopes DC, Ferreira AS, Barreto SLT, Euclides RF. Brazilian tables for poultry and swine: composition of feedstuffs and nutritional requirements. 3 rd ed. Viçosa: UFV; 2011.

17. Matterson LS, Potter LM, Stutz MW, Singsen EP. The metabolizable energy of feed ingredients for chickens. Research Report. 1965;7(1):3-11.

18. Ferreira DF. Sistemas de análises estatísticas para dados balanceados. Lavras: UFLA/ DEX/ SISVAR, 2003, 145p.

Cienc. anim. bras., Goiânia, v.20, 1-10, e-46537, 2019 
19. Calderano AA, Gomes PCG, Albino LFT, Rostagno SR, Souza RM, Mello HHC. Chemical and energetic composition of feedstuffs of plant origin for poultry at different ages. Revista Brasileira de Zootecnia [Internet]. 2010;39(2):320-326. Available from: http://www.scielo.br/pdf/rbz/v39n2/14.pdf Portuguese

20. Carvalho CB, Dutra JR WM, Rebbelo CB, Lima SBP, Takata NM, Nascimento GR. Nutritional evaluation of cottonseed meal in high energy performance and carcass characteristics of broilers. Ciência Rural [Internet]. 2010;40(5):1166-1172. Available from: http://www.scielo.br/pdf/cr/v40n5/a589cr231.pdf Portuguese

21. Donkoh A, Kotoku V. Nutritive value of feedstuffs for poultry in Ghana: chemical composition, apparent metabolizable energy and ileal amino acid digestibility. Livestock Research for Rural Development [Internet]. 2009;21(3):32 Available from: http://www.lrrd.org//rrd21/3/donk21032.htm Portuguese

22. Babiker MS, Kijora C, Abbas SA, Danier J. Nutrient composition os mean poultry feed ingredientes used in Sudan and their variations from local stantard tables values. International Journal Poultry Science [Internet]. 2009;8(4)355-358. Available from: http://citeseerx.ist.psu.edu/viewdoc/ download?doi=10.1.1.580.1234\&rep=rep1\&type=pdf English

23. Rezende IMB; Dutra JR WM, Rezende FM, Palhares LO, Ludke MCMM, Rabello CB. Digestibility of the cottonseed meal with or without addition of protease and phytase enzymes in swine diet. Acta Scientiarum: Animal Sciences [Internet]. 2012;34(3):259-265. Available from: http://periodicos.uem.br/ojs/index.php/ ActaSciAnimSci/article/view/12360/pdf_1 English

24. Santos MJB, Ludke MCMM, Ludke JV, Torres TR, Lopes LS, Bryto MS. Chemical composition and metabolizable energy values of alternative ingredients for broilers. Ciência Animal Brasileira [Internet]. 2013;14(1):32-40. Avaiable from: http://www.scielo.br/pdf/cab/v14n1/05.pdf Portuguese

25. Junqueira OM, Duarte KF, Cancherini LC, Araújo LF, Oliveira MC, Garcia EA. Chemical composition, metabolizable energy and digestible amino acids values of rice by-products for broilers. Ciência Rural [Internet]. 2009;39(8):2497-2503. Available from: http://www.scielo.br/pdf/cr/v39n8/a338cr629.pdf Portuguese

26. Nunes RV, Rostagno HS, Gomes PC, Nunes CGV, Pozza PC, Araujo MS. Coefficient of metabolizability of gross energy of different ingredients for broiler chickens. Revista Brasileira de Zootecnia [Internet]. 2008;37(1):89-94. Available from: http://www.scielo.br/pdf/rbz/v37n1/v37n1a13.pdf Portuguese

27. Silva EP, Rabello CB, Lima MB, Loureiro RRS, Guimarães AAS, Dutra JR WM. Energetic values of some conventional feeds for laying hens. Ciência Animal Brasileira [Internet]. 2009;10(1):91-100. Available from: https://www.revistas.ufg.br/vet/article/view/2482/4575 Portuguese

28. Nunes RV, Rostagno HS, Albino LFT, Gomes PC, Toledo RS. Chemical Composition, Metabolizable Energy and Energy Prediction Equations of Wheat Grain and Wheat By-Products for Broiler Chicks. Revista Brasileira de Zootecnia. 2001;30(3):785-793.

29. Batal AB, Parsons CM. Effects of age on nutriente digestibility in chicks fed different diets. Poultry Science [Internet]. $2002 ; 81(3): 400-407$. Available from: https://doi.org/10.1093/ps/81.3.400 English

30. Sakomura NZ, Bianchi MD, Pizauro JMJ, Café MB, Freitas ER. Efeito da Idade dos Frangos de Corte na Atividade Enzimática e Digestibilidade dos Nutrientes do Farelo de Soja e da Soja Integral. Revista Brasileira de Zootecnia [Internet]. 2004;33(4):924-935. Available from: http://www.scielo.br/pdf/rbz/v33n4/22089.pdf Portuguese

31. Pontalti GC, Ebling PD, Villanueva EP, Teixeira LG, Ribeiro AML. Full fat rice bran processed by infrared in different time periods in broiler diets. Ciência Rural [Internet]. 2014;44(3):561-566. Available from: http:// www.scielo.br/pdf/cr/v44n3/a7414cr2013-0869.pdf Portuguese 